\title{
Antigen of 49.6-kDa subunitpili protein of Helicobacter pylori as a potential biomarker for early and rapid detection of the infection
}

\author{
Hamong Suharsono ${ }^{1}$, Zainul Muttaqin ${ }^{2}$, I Wayan Masa Tenaya ${ }^{3}$, Kadek Karang Agustina ${ }^{4}$ and Sumarno Retro Prawiro ${ }^{5}$ \\ 1. Laboratory of Biochemistry, Faculty of Veterinary Medicine, Udayana University, Denpasar, Indonesia; 2. Biomedical \\ Research Unit, West Nusa Tenggara General Hospital, Lombok, Indonesia; 3. Animal Diseases Investigation Center, \\ Denpasar, Indonesia; 4. Department of Veterinary Public Health, Faculty of Veterinary Medicine, Udayana University, \\ Denpasar, Indonesia; 5. Laboratory of Microbiology, Medical Faculty of Brawijaya University, Malang, Indonesia. \\ Corresponding author: Hamong Suharsono, e-mail: hamong@unud.ac.id \\ Co-authors: ZM: za_taq@yahoo.com, IWMT: wayanmasatenaya62@gmail.com, \\ KKA: k.agustina@unud.ac.id, SRP: retoprawiros@yahoo.com \\ Received: 16-01-2019, Accepted: 09-04-2019, Published online: 10-06-2019
}

doi: 10.14202/vetworld.2019.769-773 How to cite this article: Suharsono H, Muttaqin Z, Tenaya IWM, Agustina KK, Prawiro SR (2019) Antigen of 49.6-kDa subunit pili protein of Helicobacter pylori as a potential biomarker for early and rapid detection of $H$. pylori infection, Veterinary World, 12(6): 769-773.

\begin{abstract}
Background and Aim: Helicobacter pylori infection has been identified as a major cause of peptic ulcer diseases, including gastric and duodenal ulcers, gastritis, chronic and gastric carcinoma, and even gastric lymphoma. In vitro studies using Western blotting analysis, hemagglutination test, adherence inhibition assays, and immunocytochemical staining revealed that the 49.6-kDa subunit pili protein of $H$. pylori was considered an immunogenic protein. This study aimed to develop a serological diagnostic test using $49.6 \mathrm{kDa}$ for detecting antibodies against $H$. pylori proteins in an early phase of the infection.
\end{abstract}

Materials and Methods: An in-house immunochromatographic test (ICT) kit was developed and used to test a panel of sera sample obtained from a randomly selected symptomatic patient, in which 40 sera were $H$. pylori positive and 40 sera were $H$. pylori negative.

Results: The results showed that ICT with $49.6 \mathrm{kDa}$ as an antigen was highly sensitive and specific for detecting anti- $H$. pylori immunoglobulin $\mathrm{G}$ antibodies in human serum, with a high negative predictive value.

Conclusion: The developed test could be used to exclude H. pylori infection in symptomatic patients.

Keywords: 49.6-kDa pili protein, Helicobacter pylori, immunochromatographic test.

\section{Introduction}

Infection by Helicobacter pylori has been identified as a major cause of peptic ulcer diseases (gastric and duodenal ulcers), gastritis, chronic and gastric carcinoma, and even gastric lymphoma [1,2]. H. pylori, also known as a zoonotic agent, is isolated from cow, sheep, and goat [3], and its antigens were detected in the milk and feces of cows [4]. This is unique because $H$. pylori is the only bacterium known to cause gastric carcinoma [5-7].

Infectious $H$. pylori was classified as carcinogen group I for gastrointestinal cancer because it has various virulent factors, such as CagA, VacA, Urease, and ammonia, that are capable of triggering carcinogenesis [5,8-10]. The pathogenic properties of these bacteria were associated with its fimbrial adhesion (pili) [11], a protein found on the bacterial cell surface that plays a role as a bacterial virulence factor [12]. In vitro studies using Western blotting

Copyright: Suharsono, et al. Open Access. This article is distributed under the terms of the Creative Commons Attribution 4.0 International License (http://creativecommons.org/licenses/ by/4.0/), which permits unrestricted use, distribution, and reproduction in any medium, provided you give appropriate credit to the original author(s) and the source, provide a link to the Creative Commons license, and indicate if changes were made. The Creative Commons Public Domain Dedication waiver (http:// creativecommons.org/publicdomain/zero/1.0/) applies to the data made available in this article, unless otherwise stated. analysis, hemagglutination test, adherence inhibition assays, and immunocytochemical staining revealed that the $49.6-\mathrm{kDa}$ subunit pili protein of $H$. pylori was immunogenic [13]. The ability of this protein in agglutinating mouse erythrocytes indicates that it was hemagglutinin in nature [13]. It was also confirmed that the protein possessed adhesion molecules that play a crucial role in the early phase of the pathogenesis when $H$. pylori infiltrate into the epithelial cells of gastric [14-16].

Further study is required to investigate the diagnostic value of this protein in the early detection of infection by this microorganism. Most diseases present high cure rates only when detected early [17]. Therefore, early diagnosis is essential to reduce morbidity and mortality. In addition, early diagnosis of infectious diseases can prevent their development into epidemics. There are several methods to detect H. pylori infection $[18,19]$. Detection of $H$. pylori infection by using serological methods is considered to be the easiest, non-invasive approach, which does not require endoscopy to diagnose the infection [20,21]. This method requires only a few drops of blood, producing results in $<5 \mathrm{~min}$ [22]. There are numerous methods available for the detection of anti-H. pylori immunoglobulin G (IgG), immunoglobulin A, and immunoglobulin $\mathrm{M}$ antibodies [23], which are present 
in the whole blood, serum, saliva, stool, and urine. The accuracy of the diagnostic markers varies from test to test and among sample types $[24,25]$. In the present study, we evaluated the performance of a new immunochromatographic test (ICT) kit using 49.6-kDa pili protein.

\section{Materials and Methods}

\section{Ethical approval}

This research was approved by the Ethical Commission for the Use of Animals in Research and Education of the Faculty of Veterinary Medicine, Udayana University, Indonesia with Ref. No. 284a/ KE-PH/VII/2017.

\section{H. pylori strains}

Three H. pylori Lombok isolates were provided by the Microbiology Laboratory, Biomedical Research Unit, West Nusatenggara General Hospital, which were isolated from the gastric antral biopsies of Sasak Lomboknese patients. The bacterium was first cultured using media Trypticase Soy Agar and Trypticase Soy Broth supplemented with $10 \%$ sheep blood, completed with supplement and IsoVitale $\mathrm{X}^{\mathrm{TM}}$, and incubated at $37^{\circ} \mathrm{C}$ on the microaerophilic atmosphere [13].

Isolation of 49.6-kDa subunit pili protein of $\boldsymbol{H}$. pylori Isolation of $H$. pylori pili was performed by the method of Sumarno et al. [26] with a slight modification. Bacteria pili were cut by using a pili bacterial cutter, which was carried out for $30 \mathrm{~s}$ at the speed of $5000 \mathrm{rpm}$ and repeated for five times. Subsequently, the isolation of pili fraction by centrifugation of cutting result was done at $12,000 \mathrm{rpm}$ at $4^{\circ} \mathrm{C}$. The supernatant containing the bacterial pili was analyzed in sodium dodecyl sulfate-polyacrylamide gel electrophoresis. Protein of $49.6-\mathrm{kDa}$ subunit pili was isolated from the gel by cutting alongside close to the protein positions, around $49.6 \mathrm{kDa}$. The isolated gel was sliced and inserted into the dialysis membrane soaked with phosphate-buffered saline (PBS). Subsequently, the protein of interest was electroeluted by placing the membrane in the negative electrode with current of $20 \mathrm{~mA}$ for $15 \mathrm{~min}$. Total protein was measured using a method ofdetergent-compatible protein assay (Bio-Rad Laboratories Inc, USA), suspended to a concentration of about $10 \mathrm{ng} / \mathrm{ml}$, and kept at $-20^{\circ} \mathrm{C}$ until use [13].

\section{Sera panel from dyspepsia patients and vaccinated mice \\ Human sera}

Eighty sera from $H$. pylori-positive and H. pylori-negative patients based on the culture and direct microscopic examination of mucosal gastric biopsy were used as panel sera. All sera of dyspepsia patients were provided by the Biomedical Research Unit, West Nusa Tenggara General Hospital, and stored at $-20^{\circ} \mathrm{C}$.

\section{Mouse sera}

One hundred healthy male balb/c mice (weight 18-22 g) were used in this study for producing animal sera. The experimental mice were grouped into 10 groups and fed with a portion of commercial food and water ad libitum. All mice were orally given culture of live H. pylori, they had been fasted one night. The $H$. pylori obtained from a patient with typical gastric ulcer was first cultured with Brain Heart Infusion media supplemented with 5\% sheep blood, incubated at microaerophilic condition $\left(10 \% \mathrm{CO}_{2}, 85 \% \mathrm{~N}_{2}\right.$, and $5 \% \mathrm{O}_{2}$ ) at $37^{\circ} \mathrm{C}$ for $48 \mathrm{~h}$. The cells were then washed and suspended with sterile PBS at a concentration of $109 \mathrm{cells} / \mathrm{ml}$. The $100 \mathrm{balb} / \mathrm{c}$ mice were divided into two groups of $\mathrm{A}$ and $\mathrm{B}$, with $50 \mathrm{balb} / \mathrm{c}$ mice each. Each animal in Group A was orally infected with 109 cells $/ \mathrm{ml} 3$ times every 2 days, based on the method of Marchetti et al. [27] In contrast, all animals in Group B were used as control animals that were orally given sterile PBS containing no $H$. pylori culture. Blood samples were collected from both Groups A and $\mathrm{B}$ before they were orally infected with the bacterial culture, and 1,2, and 3 weeks after the infection. The blood samples were collected from the tail and kept at room temperature (RT) for $2-5 \mathrm{~h}$ before the sera were collected and stored at $-20^{\circ} \mathrm{C}$ until tested.

\section{Development of IgG $\boldsymbol{H}$. pylori ICT}

A standard ICT strip typically consists of five parts: Sample (polyester) pad, conjugation (polyester) pad, nitrocellulose (NC) membrane, absorption pad, and polyvinyl chloride plastic backed card. All the pretreated parts were assembled sequentially on a plastic backing card with 2-mm overlap of each component. Antigens (49.6 kDa-sub-unit protein pili or secretory antigen $[\mathrm{Ag}]$ ) were coated separately to serve as test line and goat anti-mouse IgG as control line [28]. Both antigens and antibodies were dispensed by XYZ dispensing system (BioDot Inc, USA) to NC membrane. The Protein A-colloidal gold (CG) conjugate was dispensed onto the polyester pad. After being dried at $37^{\circ} \mathrm{C}$, the assembly was cut into a 5 -mm-wide individual strip and then stored at the RT inside a sealed plastic bucket with a desiccant until used. When a serum sample is added onto the sample pad, the sample flowed from this component to the absorption pad on the membrane surface by capillary action. Once the sample reached specific positions, the antigen in the sample reacted with the conjugates (labeled with CG). The residual sample continues to move forward and be absorbed in the absorption pad. After the reaction was completed, two lines appeared on the strip: The C-line (control line to confirm whether the strip is valid) and the T-line (test line used to judge the detection results) [29].

\section{Detection of antibodies in patient serum}

The ICT cards were removed from the foil pouch and placed on a flat, dry surface. A drop (20-30 $\mu \mathrm{l})$ of serum was applied on to the sample well. Then, two drops of the buffer were added on to the sample well. As the test began to work, purple color was seen moving across the result window at the center of the 
test disk. Test results were interpreted within $20 \mathrm{~min}$. The presence of two-color bands, "T" and "C" " meant that the test was positive, whereas the presence of only one band (only on "C") was interpreted as negative. If no band or a single band only on " $\mathrm{T}$ " was formed after $20 \mathrm{~min}$, the result was considered invalid, and the experiment was repeated [30].

\section{Results}

\section{Demographic and geographic characteristics}

We used 80 sera from dyspepsia patients undergoing an endoscopic examination at the West Nusatenggara Province General Hospital. Demographic characteristics of gastric disease patients are shown in Table-1.

The average age of the patients was 48.22 years. The representation per age group was $4(5.0 \%)$ patients under 30 years; 60 patients $(75.0 \%)$ between 30 and 50 years; and 16 patients $(20.0 \%)>50$ years. Considering the age, most of the patients were adult; hence, the diagnosis resulted in chronic $H$. pylori infection [31].

\section{Antigen 49.6-kDa subunit pili protein of $\boldsymbol{H}$. pylori}

The result of Western blotting analysis for detecting the $49.6-\mathrm{kDa}$ subunit pili protein of $H$. pylori is shown in Figure-1.

\section{Comparison of IgG $\boldsymbol{H}$. pylori detection results}

The presence of specific antibodies in mice which had been infected orally using the culture of live H. pylori was demonstrated using a standard ICT. Strong and specific reaction was observed when the subunit protein pili Ag reacted with the mouse sera 3 weeks after the infection. However, a negative reaction was observed when the sera were reacted with the secretory Ag (Figure-1). The prevalence of the serological reaction depended on the time after the infection; the highest prevalence of $96 \%$ was observed 3 weeks after the initial infection (Table-2).

Strong positive reaction in B (subunit protein pili Ag) was observed in sera of mice 3 weeks after

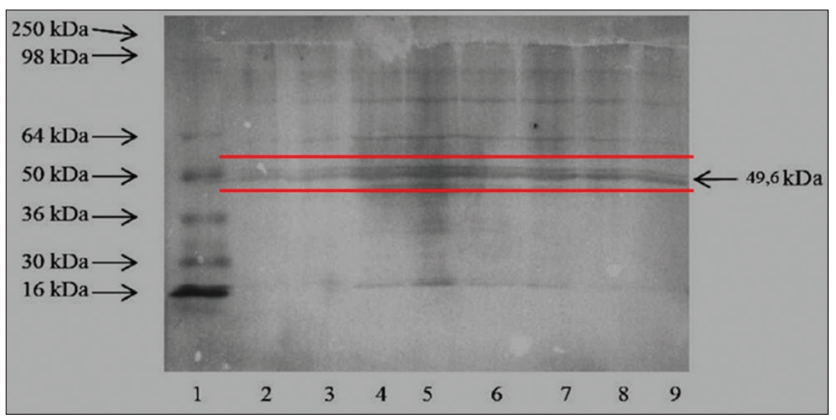

Figure-1: Western blot analysis of protein subunit pili protein from sequential cutting $H$. pylori against rabbit polyclonal anti- $H$. pylori shows that the polyclonal antibodies react strongly with subunit pili protein with a molecular weight of about $49.6 \mathrm{kDa}$, compared to other protein components. Lanes: 1. Molecular weight marker, 2-9: Protein fractions. the infection. No reaction was observed with the same sera in B (secretory Ag) [32].

The presence of specific antibodies against secretory Ag and subunit pili Ag in dyspepsia patients undergoing endoscopic was demonstrated using in vitro studies employing ICT. The subunit protein pili reacted 37 out of the 40 sera from an infected human with a specificity of $92.5 \%$ (true-positive detection) and detected only 1 out of the 40 sera $(2.5 \%)$ (false-negative reaction) from the non- $H$. pylori-infected patients. Although the ICT secretory Ag reacted with sera from an infected human with a specificity of $95 \%$, this protein also reacted with 5 out of the 40 sera $(12.5 \%$ ) (false negative) from the non- $H$. pylori-infected patients, suggesting that this protein was less specific than the 49.6 kDa-sub-unit pili protein of H. pylori (Table-3).

Table-1: Demographic characteristics.

\begin{tabular}{lc}
\hline Characteristics & $\mathbf{n}(\mathbf{\%})$ \\
\hline Sex & \\
Male & $52(65.0)$ \\
Female & $28(35.0)$ \\
Age (years) & \\
$\quad<30$ & $4(5.0)$ \\
$30-50$ & $60(75.0)$ \\
$>50$ & $16(20.0)$ \\
Ethnicity & \\
Sasak (Lomboknese) & $66(82.5)$ \\
Balinese & $12(15.0)$ \\
Other & $2(2.5)$ \\
Endoscopy diagnosis & \\
Chronic gastritis & $58(72.5)$ \\
Gastric or DU & $14(17.5)$ \\
GC & $8(10.0)$ \\
\hline
\end{tabular}

$\mathrm{GC}=$ Gastric cancer, $\mathrm{DU}=$ Duodenal ulcer

Table-2: Comparison of ICT result between subunit pili $\mathrm{Ag}$ and secretory $\mathrm{Ag}$ to detect the presence of IgG anti-Helicobacter pylori prepared from vaccinated mouse sera.

\begin{tabular}{lccc}
\hline Testing result & \multicolumn{3}{c}{$\begin{array}{c}\text { Post-infected mouse } \\
\text { sera (n=50) }\end{array}$} \\
\cline { 2 - 4 } & 1 week & 2 weeks & 3 weeks \\
\hline Secretory Ag ICT & $0(0)$ & $2(4)$ & $39(78)$ \\
$\quad$ Positive & $50(100)$ & $48(96)$ & $11(22)$ \\
$\quad$ Negative & $0(0)$ & $17(34)$ & $48(96)$ \\
Subunit pili Ag ICT & & $33(66)$ & $2(4)$ \\
$\quad$ Positive & $50(100)$ & & \\
Negative & &
\end{tabular}

IgG=Immunoglobulin G

Table-3: ICT result of secretory $\mathrm{Ag}$ and subunit pili $\mathrm{Ag}$ to detect the antibody of $H$. pylori in panel sera of $H$. pylori.

\begin{tabular}{lcc}
\hline $\begin{array}{l}\text { Testing } \\
\text { result }\end{array}$ & . pylori $(+)(\mathbf{n = 4 0 )} \boldsymbol{H}$. pylori $(-)(\mathbf{n}=\mathbf{4 0})$ \\
\hline ICT secretory Ag & & \\
$\quad$ Positive & 38 & 5 \\
$\quad$ Negative & 2 & 35 \\
ICT subunit pili Ag & & \\
Positive & 37 & 1 \\
Negative & 3 & 39 \\
\hline
\end{tabular}

H. pylori=Helicobacter pylori 


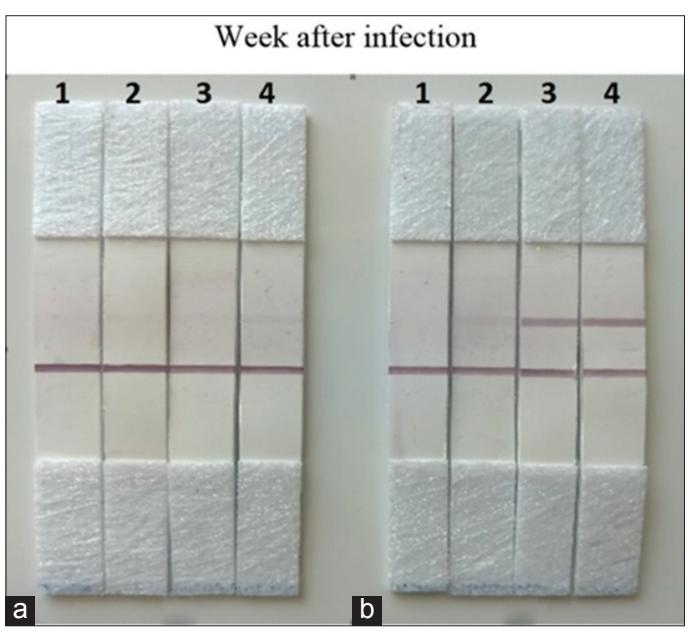

Figure-2: Test result of the different strip to detect antibody against $H$. pylori antigen in $H$. pylori-infected mouse sera: (a) Secretory Ag and (b) subunit protein pili Ag.

\section{Discussion}

H. pylori infection can be diagnosed using either invasive or non-invasive approaches [33]. Among the non-invasive approaches, serological techniques are widely used because they are cost-effective, simple, and quick $[22,34]$. However, it is unreliable to differentiate between active and previous infections [18]. Due to this condition, it was considered essential to develop a serological test to evaluate the progression of infection, especially in conjunction with eradication therapy. Therefore, a new non-invasive diagnostic test developed based on the detection of $H$. pylori IgG in this study was found to be a reliable test for detecting antibodies against $H$. pylori proteins. Using ICT test, both the $49.6 \mathrm{kDa}-\mathrm{sub}$-unit pili protein of $H$. pylori and ICT secretory Ag were found to be sensitive in detecting the presence of antibodies in vaccinated mice, from the $2^{\text {nd }}$ week after vaccination. However, the 49.6 kDa-sub-unit pili protein was more sensitive than ICT secretory Ag. The first antigen demonstrated 34\% and $96 \%$ of positive reaction at the $2^{\text {nd }}$ and $3^{\text {rd }}$ weeks after the infection. Meanwhile, the second protein showed positive reaction of $4 \%$ and $78 \%$ at the $2^{\text {nd }}$ and $3^{\text {rd }}$ weeks, respectively (Figure-2). The use of the prepared antigen to test sera from dyspepsia patients undergoing endoscopy using the ICT test showed that it reacted 37 out of the 40 sera from an infected human with a specificity of $92.5 \%$ and detected 1 out of the 40 sera $(2.5 \%)$ from the non- $H$. pylori-infected patients. Although the ICT secretory Ag reacted with sera from an infected human with a specificity of $95 \%$, this protein also reacted with 5 out of the 40 sera (12.5\%) from the non- $H$. pylori-infected patients, suggesting that this protein was less specific than the $49.6-\mathrm{kDa}$ sub-unit pili protein of $H$. pylori.

\section{Conclusion}

In this study, a specific 49.6-kDa sub-unit pili protein was found to be a potential biomarker for the early and specific detection of $H$. pylori infection.
From two antigens compared in this study, both secretory Ag ICT and sub-unit pili Ag ICT recognized specific antibodies that were prepared from mice experimentally infected with live $H$. pylori and from dyspepsia patients undergoing endoscopy. However, the $49.6-\mathrm{kDa}$ sub-unit pili protein of $H$. pylori was found to be more sensitive than the secretory Ag, which could detect the presence of targeted antibodies in the $2^{\text {nd }}$ week after vaccination in mice. Moreover, the $49.6-\mathrm{kDa}$ sub-unit pili protein demonstrated true-positive detection of $92.5 \%$ and true-negative detection of $97.5 \%$ in human sera. In contrast, the secretory Ag ICT showed true-positive and true-negative detection of $95 \%$ and $87.5 \%$, respectively. It was concluded that a feasible serological test developed in this study, using a specific 49.6-kDa sub-unit pili protein of $H$. pylori, was considered to be an important antigen used in serological tests for monitoring dyspepsia patients undergoing endoscopy; therefore, it was recommended to apply this protein in serological test for the detection of $H$. pylori infection in humans.

\section{Authors' Contributions}

HS: Designed and managed this research, did laboratory works, and wrote the manuscript; ZM: Collected samples and wrote the manuscript; IWMT: Did laboratory works, analyzed the data, and wrote the manuscript; KKA: Analyzed the data and wrote the manuscript; SRP: Designed the research, analyzed the data, and wrote the manuscript. All authors read and approved the final manuscript.

\section{Acknowledgments}

The authors would like to thank Rector of Udayana University, Indonesia for funding and supporting this research through Group Research Grant with contract no. 673-17/UN14.4A/LT/2017. They would also like to thank Dr. Haris Widita and the staff of the Endoscopy Unit of West Nusatenggara General Hospital for their kind help with specimen collection and medical record data support.

\section{Competing Interests} interests.

The authors declare that they have no competing

\section{Publisher's Note}

Veterinary World remains neutral with regard to jurisdictional claims in published institutional affiliation.

\section{References}

1. Parsonnet, J., Friedman, G.D., Vandersteen, D.P., Chang, Y., Vogelman, J.H., Orentreich, N. and Sibley, R.K. (1991) Helicobacter pylori infection and the risk of gastric carcinoma. N. Engl. J. Med., 325(16): 1127-1131.

2. Kusters, J.G., van Vliet, A.H.M. and Kuipers, E.J. (2006) Pathogenesis of Helicobacter pylori infection. Clin. Microbiol. Rev., 19(3): 449-490.

3. Momtaz, H., Dabiri, H., Souod, N. and Gholami, M. (2014) Study of Helicobacter pylori genotype status in cows, sheep, 
goats and human beings. BMC Gastroenterol. 14(61): 1-7.

4. Safaei, H.G., Rahimi, E., Zandi, A. and Rashidipour, A. (2011) Helicobacter pylori as a zoonotic infection: The detection of $H$. pylori antigens in the milk and feces of cows. J. Res. Med. Sci., 16(2): 184-187.

5. IARC Working Group.(1994) Helicobacter pylori. IARC Monographs 100B. Pp. 385-435.

6. Tokudome, S., Soeripto, S.W.D., Triningsih, F.X., Suzuki, S., Hosono, A., Triono, T., Sarjadi, I.W., Miranti, I.P., Ghadimi, R. and Moore, M.A. (2005) Helicobacter pylori infection appears essential for stomach carcinogenesis: Observations in Semarang, Indonesia. Cancer Sci., 96(12): 873-875.

7. Wroblewski, L.E., Peek, J.R.M. and Wilson, K.T. (2010) Helicobacter pylori and gastric cancer: Factors that modulate disease risk. Clin. Microbiol. Rev., 23(4): 713-739.

8. Azuma, T., Yamazaki, S., Yamakawa, A., Ohtani, M., Muramatsu, A., Suto, H., Ito, Y., Dojo, M., Yamazaki, Y., Kuriyama, M., Keida, Y., Higashi, H. and Hatakeyama, M. (2004) Association between diversity in the Src homology 2 domain containing tyrosine phosphatase binding site of Helicobacter pylori CagA protein and gastric atrophy and cancer. J. Infect. Dis., 189(5): 820-827.

9. Satomi, S., Yamakawa, A., Matsunaga, S. and Masaki, R. (2006) Relationship between the diversity of the cagA gene of Helicobacter pylori and gastric cancer in Okinawa, Japan. J. Gastroenterol., 41(7): 668-673.

10. Batista, S.A., Rocha, G.A., Rocha, A.M., Saraiva, I.E., Cabral, M.M., Oliveira, R.C. and Queiroz, D.M. (2011) Higher number of Helicobacter pylori CagA EPIYA C phosphorylation sites increases the risk of gastric cancer, but not duodenal ulcer. BMC Microbiol., 11(61): 1-7.

11. Johnson, E.M., Gaddy, J.A., Voss, B.J., Hennig, E.E. and Cover, T.L. (2014) Genes required for assembly of pili associated with the Helicobacter pylori cag Type IV secretion system. Infect. Immun., 82(8): 3457-3470.

12. Salyer, A.A. and Whitt, D.D. (2002) Bacterial Pathogenesis a Molecular Approach. ASM Press, Washington DC. p115-127.

13. Suharsono, H., Hendrayana, M.A., Astawa, I.N.M. and Prawiro, S.R. (2014) Confirmation of adherence protein hemagglutinin sub-unit pili with MW 49.6 kDa Helicobacter pylori on mice gastric epithelial cell. IOSR J. Pharm. Biol. Sci., 9(2): 59-66.

14. Alzahrani, S., Lina, T.T., Gonzalez, J., Pinchuk, I.V., Beswick, E.J. and Reyes, V.E. (2014) Effect of Helicobacter pylori on gastric epithelial cells. World J. Gastroenterol., 20(36): 12767-12780.

15. Roesler, B.M., Rabelo-Gonçalves, E.M.A. and Zeitune, J.M.R. (2014) Virulence factors of Helicobacter pylori: A review. Clin. Med. Insights Gastroenterol., 2014(7): 9-17.

16. Huang, Y., Wang, Q., Cheng, D., Xu, W. and Lu, N. (2016) Adhesion and invasion of gastric mucosa epithelial cells by Helicobacter pylori. Front. Cell. Infect. Microbiol., 6(159): $1-11$.

17. Weatherall, D., Greenwood, B., Chee, H.L. and Wasi, P. (2006) Science and technology for disease control: Past, present, and future. In: Jamison, D.T., Breman, J.G., Measham, A.R., Alleyne, G., Claeson, M. and Evans, D.B., editors. Disease Control Priorities in Developing Countries. $2^{\text {nd }}$ ed. Oxford University Press, New York.

18. Khalifehgholi, M., Shamsipour, F., Ajhdarkosh, H., Daryani, N.E. and Pourmand, M.R., Hosseini, M., Ghasemi, A. and Shirazi, M.H. (2013) Comparison of five diagnostic methods for Helicobacter pylori. Iran. J. Microbiol., 5(4): 396-401.
19. Garza-González, E., Perez-Perez, G.I., MaldonadoGarza, H.I. and Bosques-Padilla, F.J. (2014) A review of Helicobacter pylori diagnosis, treatment, and methods to detect eradication. World J. Gastroenterol., 20(6): 1438-1449.

20. Herbrink, P. and van Doorn, L.J. (2000) Serological methods for diagnosis of Helicobacter pylori infection and monitoring of eradication therapy. Eur. J. Clin. Microbiol. Infect. Dis., 19(3): 164-173.

21. Shukla, S., Pujani, M., Agarwal, A., Pujani, M. and Rohtagi, A. (2012) Correlation of serology with morphological changes in gastric biopsy in Helicobacter pylori infection and evaluation of immunohistochemistry for $H$. pylori identification. Saudi J. Gastroenterol., 18(6): 369-374.

22. Daivasikamai, P. (2014) Advantages of serological testing for Helicobacter pylori infection as a screening test. Int. J. Adv. Med., 1(3): 217-221.

23. She, R.C., Wilson, A.R. and Litwin, C.M. (2009) Evaluation of Helicobacter pylori immunoglobulin $\mathrm{G}$ (IgG), IgA, and IgM serologic testing compared to stool antigen testing. Clin. Vaccine Immunol., 16(8): 1253-1255.

24. Wang, Y., Kuo, F., Liu, C., Wu, M., Shih, H., Wang, S.S., Wu, J.Y., Kuo, C.H., Huang, Y.K. and Wu, D.C. (2015) Diagnosis of Helicobacter pylori infection: Current options and developments. World J. Gastroenterol., 21(40): 11221-11235.

25. Miftahussurur, M. and Yamaoka, Y. (2016) Diagnostic methods of Helicobacter pylori infection for epidemiological studies: Critical importance of indirect test validation. Biomed. Res. Int., 2016(4819423): 1-14.

26. Sumarno, R.P., Uun, Y., Winarsih, S., Islam, S. and Sanarto, S. (2012) Detection of molecule adhesion sub-unit pili $48 \mathrm{kDa}$ Salmonella Typhi by immunochemistry method using sera patients suffering from typhoid fever. J. Basic Appl. Sci. Res., 2(9): 8527-8532.

27. Marchetti, M., Aricò, B., Burroni, D., Figura, N., Rappuoli, R. and Ghiara, P. (1995) Development of a mouse model of Helicobacter pylori infection that mimics human disease. Science, 267(5204): 1655-1658.

28. EMD Millipore. (2013) Rapid Lateral Flow Test Strips. EMD Millipore Corporation, Billerica, MA, Darmstadt, Germany.

29. Li, H., Yang, J., Bao, D., Hou, J., Zhi, Y., Yang, Y., Ji, P., Zhou, E., Qiao, S. and Zhang, G. (2017) Development of an immunochromatographic strip for detection of antibodies against porcine reproductive and respiratory syndrome virus. J. Vet. Sci., 18(3): 307-316.

30. Locatelli, A., Catapani, W.R., Junior, C.R.G., Silva, C.B.P. and Waisberg, J. (2004) Detection of anti-Helicobacter pylori antibodies in serum and duodenal fluid in peptic gastroduodenal disease. World J. Gastroenterol., 10(20): 2997-3000

31. Muttaqin, Z., Suharjono, Aulanni'am, A. (2016) Phylogenetic analysis of 3' region of Helicobacter pylori cagA gene of Lombok isolates and the association with gastric pathology. IOSR J. Pharm. Biol. Sci., 11(1): 1-6.

32. Kumagai, T., Yan, J., Graham, D.Y., Tozuka, M., Okimura, Y., Ikeno, T., Sugiyama, A., Katsuyama, T. and Ota, H. (2001) Serum immunoglobulin G immune response to Helicobacter pylori antigens in mongolian gerbils. $J$. Clin. Microbiol., 39(4): 1283-1288.

33. Abadi, A.T.B. (2018) Diagnosis of Helicobacter pylori using invasive and noninvasive approaches. J. Pathog., 2018(9064952): 1-13.

34. Gatta, L., Ricci, C., Tampieri, A. and Vaira, D. (2003) Non-invasive techniques for the diagnosis of Helicobacter pylori infection. Clin. Microbiol. Infect., 9(6): 489-496. 